\title{
The Dissertation Topic Selection of Doctoral Students Using Dynamic Network Analysis
}

\author{
Anthony A. Olalere and Edward De Iulio \\ Clemson University, Clemson, SC, USA
}

aaolalere@yahoo.com edeiuli@clemson.edu

\section{Amin Marei Aldarbag University of Omer Almukhtar, Libya}

ammmz71@gmail.com

\author{
Mehmet Akif Erdener \\ Necatibey School of Education, \\ Balikesir University, Bigadiç, \\ Turkey \\ erdener@balikesir.edu
}

\begin{abstract}
The significance of a doctoral student's completed dissertation is of immense importance both to the field and student. The dissertation not only signifies the candidate's ability to perform independent research, it also confirms the candidate's ability to provide original contributions to knowledge. This study examines the dissertation topic selection process of doctoral educational leadership students in order to understand what influences the student's dissertation topic selection. The emerging approach of Dynamic Network Analysis (DNA) was used to examine the interactions between task, belief, resource and knowledge in determining students' choice. Data was analyzed using the Organizational Risk Analyzers' (ORA) software measures of Newman Grouping, centrality betweenness, cognitive demand, knowledge exclusivity, resource exclusivity, eigenvector centrality, and total degree centrality. The results suggest that topic selection is influenced by faculty member's research agenda, departmental core courses, and network factors like professional experience, life experience, and practical experience. This result will help doctoral students understand the influences of mentor and adviser's research interest, departmental core courses, professional experiences and life experiences as they navigate through dissertation topic selection and research.
\end{abstract}

Keywords: Doctoral Students, Dissertation Topic Selection, Dynamic Network Analysis

Material published as part of this publication, either on-line or in print, is copyrighted by the Informing Science Institute. Permission to make digital or paper copy of part or all of these works for personal or classroom use is granted without fee provided that the copies are not made or distributed for profit or commercial advantage AND that copies 1) bear this notice in full and 2) give the full citation on the first page. It is permissible to abstract these works so long as credit is given. To copy in all other cases or to republish or to post on a server or to redistribute to lists requires specific permission and payment of a fee. Contact Publisher@,InformingScience.org to request redistribution permission.

\section{Introduction}

The dissertation is the culminating feature of the doctoral program. The significance of a doctoral student's completed dissertation is of immense importance both to the field and student. Not only does the dissertation signify the candidate's ability to perform independent research, it also confirms the 
candidate's ability to provide original contributions to the field's knowledge base (Isaac, Quinlan, \& Walker, 1992; Katz, 1997; Useem, 1997). The significance of the dissertation does not stop there. The dissertation reflects more than the candidate's training, technical, analytical, and writing skills. The dissertation also impacts the close working relationship between the advisor and the candidate and the reputation of the advisor.

Additionally, since external accreditation organizations review $\mathrm{PhD}$ candidate dissertations as part of the accreditation process, the dissertation also reflects on the program, department, college, and university as well (Isaac et al., 1992; Katz, 1997). Katz (1997) also identifies society as an important player with a vital interest in the dissertation process because of its implications to research, practice and policy. Reputations of the individual, advisor, and university are all at stake in a doctoral dissertation. Isaac et al. (1992) and Useem (1997) stated that the dissertation may also play a critical role in the initial hiring of new faculty members. As long as the dissertation remains the center of the doctoral degree (Ziolkowski, 1990), it is important to study the factors that influence the selection of a dissertation topic because the lack of understanding can lead to the poor dissertation work, frustration and drop out from the doctoral program. This paper, using dynamic network analysis (DNA), suggest vital factors that might help enhance successful dissertation topic selection.

\section{Research Questions}

The following questions were examined in this research:

1. How do professors' research agendas influence a student's dissertation topic?

2. What kinds of resources (faculty and classes taken) influence a student's selection of his or her dissertation topic?

3. What is the relationship between (a) students knowledge and (b) students' belief in their research topic selection?

4. What dynamic networks do Educational Leadership graduates use to determine their dissertation topics?

\section{Literature Review}

Selecting a dissertation topic may be the most difficult and most important major decision associated with a graduate student's education (Katz, 1997; Lei, 2009). Choosing a dissertation topic is crucial, as it requires identifying one's research interest and the area of one's contribution to knowledge (Luse, Mennecke, \& Townsend, 2012). This decision should be well guided and supported by convincing reasons. There is very little literature on what constitutes the most influence on the doctoral student's selection of dissertation topic (Isaac, Koenigsknecht, Malaney, \& Karras, 1989). The preponderance of the literature focuses on writing the dissertation, the graduate student experience, and faculty/adviser student relations with scant research on the process of dissertation topic selection (Bargar \& Duncan, 1982; Dunham \& Lumsden, 1981). Even rarer is the influence of network interactions and relationships in dissertation topic selection.

Dynamic network is the context and mechanisms that enable interactions to emerge during the dissertation topic selection process. Context here refers to the interactive atmosphere while mechanism describes the patterns of behavior that produces the desired outcome. The primary outcomes of dynamic networks are adaptability, creativity, and learning (Uhl-Bien, Marion, \& McKelvey, 2007). Much of the literature contains very little advice on how to select research topics for this important task (Gatrell, 1991; Isaac et al., 1989) and almost nothing on the type of networks that influences dissertation topic research. 
Gatrell (1991) calls topic selection the most vexed issue a doctoral student faces. This is true because most students do not have research interests while others cannot select a topic from their selected research interests (Leedy \& Ormrod, 2005; Luse et al., 2012). Researchers identify some factors that influence topic selection. Lei (2009) identified factors students consider when choosing a dissertation topic. These factors include faculty and student related factors, the nature of the topic, trend, duration of study, research funding, and eventual audience of published works.

Useem (1997) identified five considerations for choosing a dissertation topic as tractability, reach, data availability, clarity of problem, resonance with organizational culture, learning new methodology, job search, and contributions to knowledge. Heiss (1967) identified students' preference, adviser area of research, peer group influence, time of completion, preliminary core classes at the doctoral level in the field of study and prevailing trend in the field, past background and the students' future job or field interests as factors that are important to the dissertation topic selection. While there were some similarities among these authors, there does not appear to be consistent factors or influences of networks that impact dissertation topic selection.

Other researchers note that if the student selects his or her own topic, there is a greater sense of commitment to and personal responsibility for the project (Adderley et al., 1975). Student topic selection also has greater relevance and meaning if the student has taken the initiative in formulating the research question (Gatrell, 1991). Initial research focusing on dissertation selection identified that a student's independence in the dissertation selection process varied among disciplines. Specifically, Berelson (1960) noted that physical sciences students have less freedom of choice in their dissertation topic selection than education students. The findings revealed freedom of choice was $2 \%$ in physical sciences, $4 \%$ in biological sciences, $7 \%$ in engineering, $9 \%$ in the humanities, $12 \%$ in social sciences, and $19 \%$ in education. A more recent work on the significance of the selection and importance of supervisors in doctoral student dissertation was examined by Ray (2007).

This study considers the dissertation selection process of doctoral students using the lenses of dynamic network analysis to examine how educational leadership graduate students determine their dissertation topic. In doing this, researchers considered the kind of resources (classes) available to the student, and the influences of their professors' research agenda in this discussion. Finally, this paper explicates the relationship between the students' knowledge and beliefs in their selection of dissertation research topic.

\section{Theoretical Framework}

\section{Network Analysis}

This paper uses network analysis as theoretical framework. Network analysis is the study of relationships between individuals, objects, or events. These relationships may consist of friendships, dominance, communications, etc. and may be mutual or one-directional with differing levels of intensity. Networks are studied according to their attributes and relationships. Attributes are considered intrinsic characteristics of people, objects, and events (i.e., gender, intelligence, income, etc.). They persist across the context studied. A relationship is an emergent property of the connection or linkage between units of observation. They are context specific and can change when an individual is removed from a study (Knoke \& Kuklinski, 1982). For this study, network analysis is divided into two categories: social network and dynamic network analysis.

Marin and Wellman (2011) state that social network analysis is neither a theory nor a methodology. Instead, a social network is a perspective or a paradigm. Social networks are based on a starting point that social life is created by the relations and the patterns they form. Network analysis allows researchers guidance on where to look for answers to relationships and connections 
within the network. Borgatti, Mehra, Brass, and Labianca (2009) believe social networks do have a theoretical understanding and can be considered a theory.

\section{Social Network}

A social network is a set of nodes tied together by one or more types of relations (Wasserman \& Faust, 1994). Nodes are units that are connected by relationships whose patterns are studied. While units are usually persons or organizations, any unit that can be connected to other units can also be studied as nodes (Marin \& Wellman, 2011). Laumann, Marsden, and Prensky (1983) identify three methods to determine which nodes to include in the network. The first node inclusion is position-based. Nodes are included based on organization membership or formally defined positions in an organization. Individuals not in the organization or in designated positions are excluded from the study. The second node inclusion method is event-based. Researchers include individuals in the network who participated in events believed to define the population. The final node inclusion method is relation-based. Researchers identify a small set of nodes found to be of interest and expand the number of nodes to include others who share relationships with previously identified nodes. Laumann et al. (1983) indicate research uses combinations of these methods to define the network and its boundaries. Once nodes are identified, researchers determine the relationships existing between these nodes.

Relationships are broad and include similarities, social relations, interactions, and flows (Borgatti et al., 2009; Wasserman \& Faust, 1994). Social relations include kinship, affective ties, or cognitive awareness. Interactions are behavior-based ties such as speaking with, helping, or inviting into one's home. They usually are connected with the social relationships. Flow relationships are exchanges or transfers between nodes. Flows include resources, information, or information as it moves through the network (Marin \& Wellman, 2011).

\section{Dynamic Network Analysis (DNA)}

One of the limitations of social networks is that they rely on having perfect information about each node and that the network is static. As a tool of analysis DNA helps to study "how entities are constrained and enabled as they interact and the process that lead to change in the interactions" (Carley, 2010, p.7). DNA allows imperfect information and the network itself can learn and adapt to varying levels of uncertainty in the network (Carley, 2003). Carley identifies three DNA advances over social network allowing the network to adapt to imperfect and changing information. First, DNA creates a meta-matrix. Using knowledge management, operations research, and social networks a meta-matrix is developed focusing on people, resources, and tasks. Second, the ties between the meta-matrix nodes are tied with probabilities. These probabilities also estimate how they change over time.

Finally, the meta-matrix uses multi-agent technology. This process creates a dynamic social network that allows people, knowledge, tasks, and other groups to co-evolve. This study uses DNA to examine doctoral students' interactions with resources (classes taken), belief, task, and people (agents) as they navigate the selection of their dissertation topic. Furthermore, the relevancy of this framework is that, while social network helps to examine the answers to influences, relationships and network patterns (perfect) as situated in the research questions, dynamic network analysis explains how agents are constrained and enabled as they interact (imperfect).

\section{Methodology}

This research highlights the doctoral student dissertation experience with a view to identifying influences that shape the students' dissertation topic. The emerging DNA methodology examines the interactions of the influence based on the variables of agent (individual), task, knowledge, and 
resource (faculty and classes). DNA is used to understand patterns of behavior among agents and the nature of these interactions. The rationale for using this method is to explain the influences that determine doctoral dissertation topic selection and understand the various interactions (relationship) between the variables identified as agents, task, knowledge, and resource as they shape students' choice.

Data for this study was collected from a doctoral research class who were in the process of writing their dissertation in a research based university situated in a rural area of south eastern United States of America. Purposeful sampling was used to capture responses from students who had completed their comprehensive examinations and are now focused on the dissertation process. These now $\mathrm{PhD}$ candidates have to complete candidacy core classes to complete the program and their dissertation.

In this study, participants were taking Advanced Seminar classes, which is the second of three required candidacy core classes. As a result, participants already taking this class were not randomly selected. A total of twenty students were emailed, using their university address questionnaires using the Qualtrics online data collection instrument. Eighteen questionnaires were completed within two weeks. This sample size consisted of traditional (full-time with university assistantship) and non-traditional students (with full time jobs). The classes' professor was contacted to engender participation from all respondents. The student population included both full and part time students in a predominantly white institution. Typically, a full time student is defined as a student with a university assistantship and enrolled in a minimum of 9 credit hours per semester. These students are considered traditional students. Part time students usually were full time employees in or outside of the university and took less than 9 credit hours per semester. They are referred to as non-traditional students. A questionnaire was used to collect data in this study which consisted of 18 questions. The questions included participant's demographic factors, relationship with other agents (students), beliefs, resources (faculty and classes) and knowledge. This study was conducted as part of the doctoral research class. As a result, time for data gathering was limited. Additionally, time constraints limited survey participants to educational leadership doctoral students.

The data collected using the Qualtrics online tool was exported to an excel spreadsheet and organized along the lines of agent (individual), task, knowledge, belief, and resources. Additionally, the names of the respondents were replaced with pseudonyms (agent 1-20). Even though three students did not reply to the questionnaires, they remained in the database since other agents referred to them in the questionnaires. Pinsonneault and Kraemer (1993) stated that data collection depends on the participants' willingness to respond to the survey questions. The data was then exported into the network analysis software called ORA. The researchers used ORA Newman Grouping, centrality betweenness, cognitive demand, knowledge exclusivity, resource exclusivity, eigenvector centrality, and total degree centrality for the data analysis of this research.

\section{Data Analysis}

Data analysis was carried out by first identifying the suitable ORA measures for this study. The measure centrality betweenness refers to a node in the network and its ability to connect groups in a network. This measure looks across all nodes that have the shortest path containing that node and percentage of paths that contain that node. The agent the node refers to is positioned to broker connections between groups and to bear the influence of one group on another or serves as a gatekeeper between groups. The measure indicates the extent the individual is a broker of indirect connections among all others in a network. Someone with high centrality betweenness is a gatekeeper of information and occurs on many of the shortest paths among other people (Freeman, 1979). 
Cognitive demand measures the total amount of cognitive effort expended by each agent to accomplish its tasks and connect with others. Strong leaders are well connected in a network (people, resources, knowledge, etc.) and are engaged in tasks where they do not have complete information (Carley, 2002). Exclusivity measures the amount of knowledge or resources that no one else possesses (Ashworth \& Carley, 2006). Eigenvector centrality identifies the strength of the relationship between nodes in a network. Nodes that are connected to many otherwise isolated individuals or organizations will have a much lower score in this measure than those that are connected to groups that have many connections themselves (Bonacich, 1972a, 1972b).

Finally, the Total Degree Centrality measures the agents "in the know". These nodes are linked to many others and, as a result of their position, have access to the ideas, thoughts, and beliefs of many others (Wasserman \& Faust, 1994). The range of these measures is zero to one. Researchers used Newman grouping to identify clusters in a network. These clusters allowed the identification of knowledge, resources, and beliefs connections and groupings in the network, even in large networks (Clauset, Newman, \& Moore, 2004).

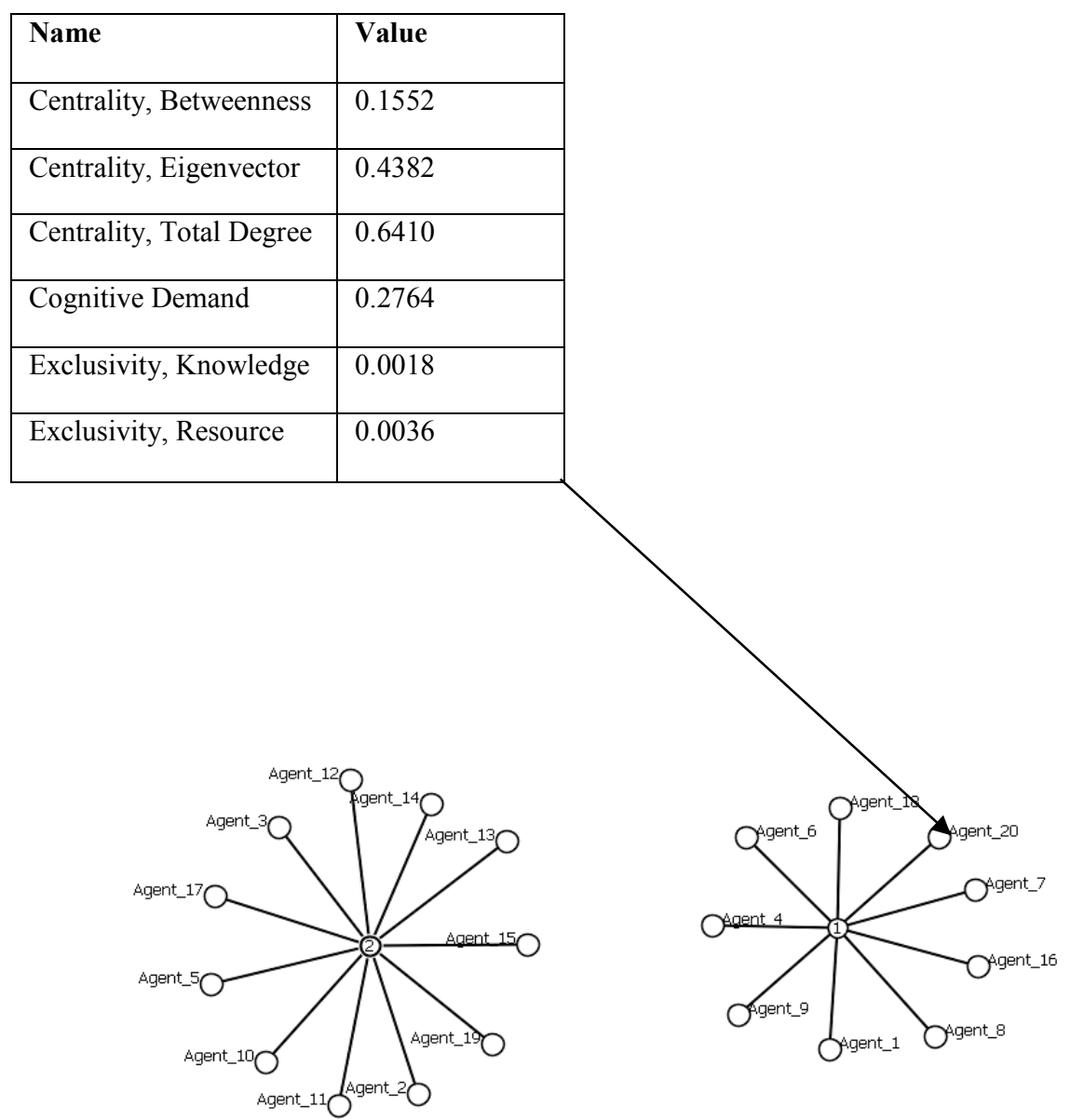

Figure 1 Agent by Agent 
Figure 1 displays the agents' interactions with each other and all measurement results are shown in Table 1. The researchers conducted DNA and used centrality-betweenness to measure agents' interactions. The eigenvector measures (on a scale of zero to one) the strength of an agent's network. The result showed (see Table 1) that agent 20 has the strongest network compared to other agents with a 0.4382 eigenvector value.

Table 1: The Measurements of Agent by Agent

\begin{tabular}{lrrrrrr}
\hline & & & & & & \\
& $\begin{array}{c}\text { Centrality, } \\
\text { Betweenness }\end{array}$ & $\begin{array}{c}\text { Cognitive } \\
\text { Demand }\end{array}$ & $\begin{array}{c}\text { Centrality, } \\
\text { Eigenvector }\end{array}$ & $\begin{array}{c}\text { Exclusivity, } \\
\text { Knowledge }\end{array}$ & $\begin{array}{c}\text { Exclusivity, } \\
\text { Resource }\end{array}$ & $\begin{array}{c}\text { Centrality, } \\
\text { Total De- } \\
\text { gree }\end{array}$ \\
\hline Agent 1 & 0.0026 & 0.1361 & 0.2254 & 0.0018 & 0.0263 & 0.2308 \\
Agent 2 & 0.0107 & 0.1624 & 0.2998 & 0.0018 & 0.0097 & 0.3077 \\
Agent 3 & 0.0054 & 0.1361 & 0.2193 & 0.0018 & 0.0097 & 0.2308 \\
Agent 4 & 0.0000 & 0.0351 & 0.1320 & 0.0000 & 0.0000 & 0.1026 \\
Agent 5 & 0.0418 & 0.1887 & 0.2806 & 0.1000 & 0.0036 & 0.3846 \\
Agent 6 & 0.0438 & 0.2414 & 0.4329 & 0.0018 & 0.0036 & 0.5385 \\
Agent 7 & 0.0121 & 0.1624 & 0.2587 & 0.0018 & 0.0263 & 0.3077 \\
Agent 8 & 0.0000 & 0.0614 & 0.2010 & 0.0000 & 0.0000 & 0.1795 \\
Agent 9 & 0.0000 & 0.1361 & 0.2194 & 0.0135 & 0.0263 & 0.2308 \\
Agent 10 & 0.0200 & 0.2063 & 0.3314 & 0.0135 & 0.0036 & 0.4359 \\
Agent 11 & 0.0000 & 0.0614 & 0.2216 & 0.0000 & 0.0000 & 0.1795 \\
Agent 12 & 0.0379 & 0.2063 & 0.3453 & 0.0135 & 0.0097 & 0.4359 \\
Agent 13 & 0.0243 & 0.1887 & 0.3409 & 0.1000 & 0.0097 & 0.3846 \\
Agent 14 & 0.0244 & 0.1887 & 0.3573 & 0.1000 & 0.0263 & 0.3846 \\
Agent 15 & 0.1064 & 0.2589 & 0.4149 & 0.0018 & 0.0263 & 0.5897 \\
Agent 16 & 0.0378 & 0.2308 & 0.3209 & 0.1018 & 0.0263 & 0.4103 \\
Agent 17 & 0.0535 & 0.2238 & 0.3610 & 0.0018 & 0.0097 & 0.4872 \\
Agent 18 & 0.0040 & 0.1624 & 0.3297 & 0.1000 & 0.0714 & 0.3077 \\
Agent 19 & 0.0254 & 0.2150 & 0.3794 & 0.0018 & 0.0097 & 0.4615 \\
Agent 20 & 0.1552 & 0.2764 & 0.4382 & 0.0018 & 0.0036 & 0.6410 \\
\hline
\end{tabular}

The Centrality betweenness value of 0.1552 (on a scale of zero to one) indicated that agent 20 found the shortest ways to connect with others in the network. Agent 20's cognitive demand value was 0.2764 . This value measures how much dissertation topic knowledge this agent has to complete their task. Agent 16 has a dissertation topic selection knowledge exclusivity value of 0.1018 and agent 18 has a dissertation topic selection resource exclusivity value of 0.0714 . These are the highest values in the respective measures. 
Table 2. The Measurements of Agent by Chair Research Agenda

\begin{tabular}{lrr}
\hline & $\begin{array}{r}\text { Centrality, } \\
\text { Eigenvector }\end{array}$ & $\begin{array}{c}\text { Centrality, } \\
\text { Total Degree }\end{array}$ \\
\hline Assessment & 0.0834 & 0.0196 \\
Athletics & 0.0000 & 0.0196 \\
Complexity/ Creativity /Networks & 0.7139 & 0.0980 \\
Distributed Learning/School Choice & 0.4060 & 0.0784 \\
Diversity & 0.0758 & 0.0392 \\
Faculty & 0.0133 & 0.0196 \\
Finance & 0.0000 & 0.0588 \\
Laws/Policy & 0.0000 & 0.0392 \\
Leadership/ Governance & 0.5590 & 0.0980 \\
Mission Creep & 0.0133 & 0.0196 \\
\hline
\end{tabular}

The dissertation chair's research interest has important effects on students' dissertation topic selection. Table 2 identifies centrality eigenvector and centrality total degree for the influence of the dissertation chairs' research interest on student dissertation topic selection. The DNA results revealed that Complexity/Creativity/Networks, Leadership/Governance, and Distributed Learning/School Choice faculty research agendas were highly influential on students' topic selections with centrality eigenvector values of $0.7139,0.5590$, and 0.4060 respectively. The centrality total degree values were $0.0980,0.0980$, and 0.0784 respectively. Figure 2 illustrates the relationship between students and their chairs' research interests.

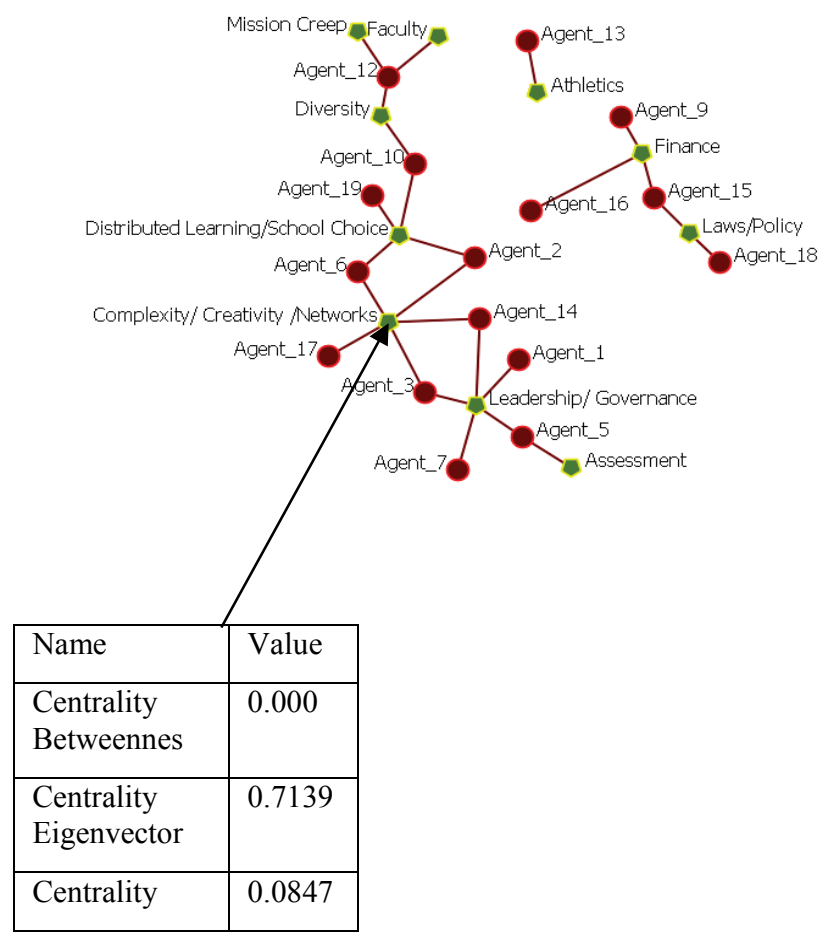

Figure 2: Agent by Chair Research Interest 
Another important factor affecting a student's dissertation topic selection is faculty influence. The regression analysis from ORA showed an $\mathrm{R}^{2}=0.4423$ for faculty influences revealing which faculty and their research interests have the greatest influence on students dissertation topic selection. Table 3 identifies the centrality eigenvector and centrality total degree for agent by faculty influences. Faculty 3 had the highest centrality eigenvector value of 0.5577 .

Table 3: The Measurement of Agent by Faculty Influences

\begin{tabular}{lrr}
\hline & $\begin{array}{c}\text { Centrality, } \\
\text { Eigenvector }\end{array}$ & $\begin{array}{l}\text { Centrality, } \\
\text { Total Degree }\end{array}$ \\
\hline Faculty 1 & 0.3208 & 0.0702 \\
Faculty 2 & 0.2370 & 0.0702 \\
Faculty 3 & 0.5577 & 0.1579 \\
Faculty 4 & 0.3296 & 0.0877 \\
Faculty 5 & 0.3333 & 0.0877 \\
Faculty 6 & 0.0709 & 0.0175 \\
Faculty 7 & 0.2786 & 0.0702 \\
Faculty 8 & 0.3753 & 0.0877 \\
Faculty 9 & 0.1967 & 0.0702 \\
Faculty 10 & 0.1288 & 0.0175 \\
Faculty 11 & 0.1735 & 0.0877 \\
Faculty 13 & 0.0357 & 0.0175 \\
\hline
\end{tabular}

Faculty $8,5,4$, and 1 were grouped closely together with centrality eigenvector values of 0.3753 , $0.3333,0.3296$, and 0.3208 respectively. Faculty 3 had the highest centrality total degree value of 0.1579 . Faculty $4,5,8$, and 11 had a centrality total degree value of 0.0877 , while Faculty 1 , 2,7 , and 9 centrality total degree was 0.0702 , and Faculty 6,10 , and 13 's centrality total degree value was 0.175 . These values imply that faculty members have a high influence on a student's dissertation topic selection. Figure 3 illustrates the Newman Grouping relationship between students and their faculty influence. 

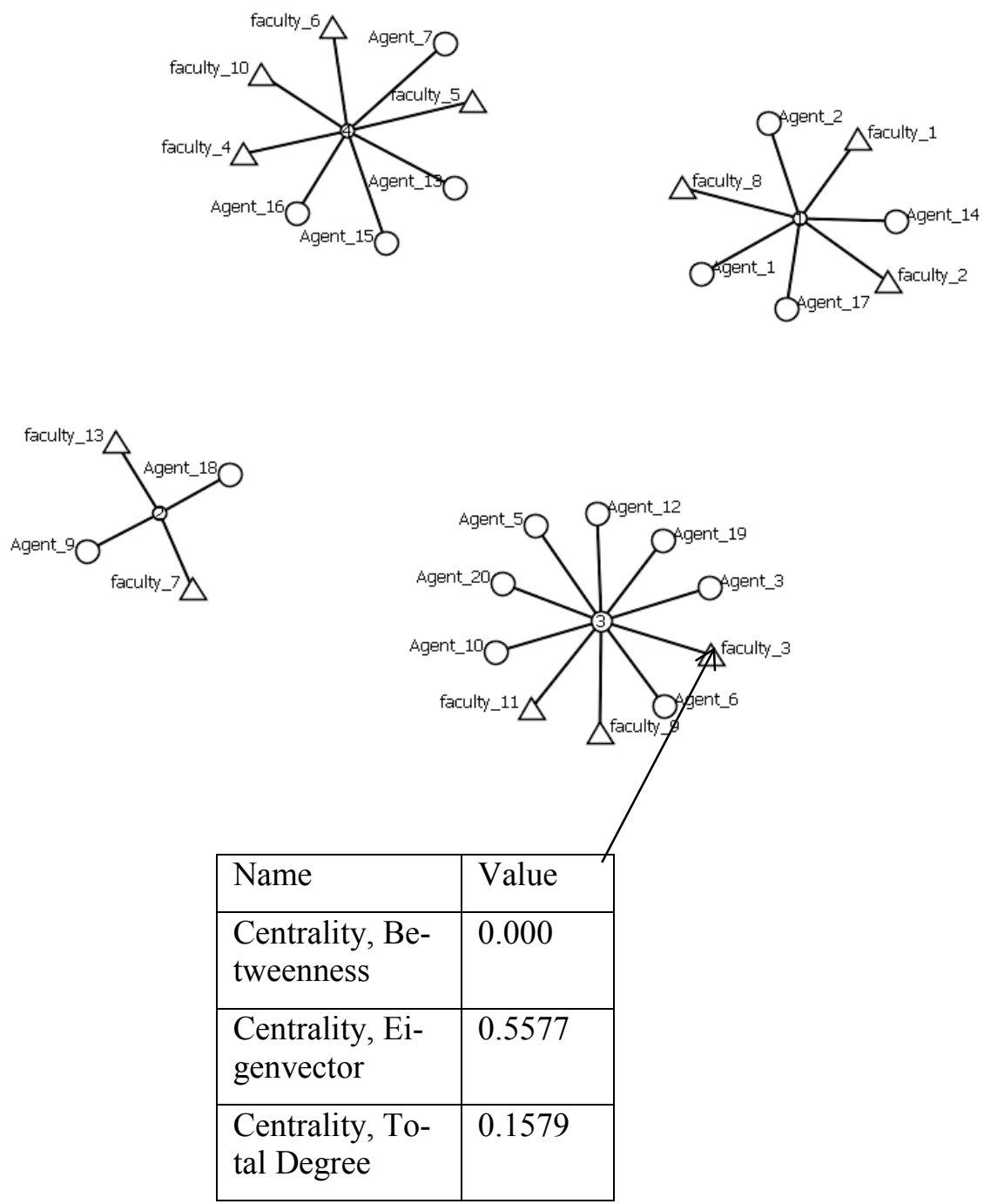

Figure 3: Agent by Faculty Influence

The other important resource that influences student dissertation topic selection is the classes completed during their PhD program. The researchers applied Newman Grouping to determine the influence classes have on students' dissertation topic selection. Applying Newman Grouping revealed eight-clusters (see Figure 4).

The result showed that the Directed Research class has the highest impact on students' topic selection with a 0.5389 eigenvector value (see Figure 4).

The interactions between students and classes are presented in Table 4, which showed that leadership courses (Principles of Educational Leadership and Theory and Practices in Educational Leadership) and research courses (Directed Research, Advanced Doctoral Seminar, Internship in Educational Leadership, and Introductory Doctoral Seminar) had eigenvector values great than 0.2 . 
Table 4. The Measures Agent by Classes

\begin{tabular}{|c|c|c|}
\hline & $\begin{array}{l}\text { Centrality, } \\
\text { Eigenvector }\end{array}$ & $\begin{array}{l}\text { Centrality, } \\
\text { Total Degree }\end{array}$ \\
\hline Research Methods in Educational Leadership & 0.1186 & 0.0230 \\
\hline Doctoral Dissertation Research & 0.1052 & 0.0230 \\
\hline $\begin{array}{l}\text { Case Study and Ethnographic Research Meth- } \\
\text { ods and Design }\end{array}$ & 0.0720 & 0.0230 \\
\hline Instructional Leadership & 0.0551 & 0.0115 \\
\hline Internship in Educational Leadership II & 0.2169 & 0.0460 \\
\hline Sociology of Higher Ed & 0.0447 & 0.0230 \\
\hline College Teaching & 0.1520 & 0.0460 \\
\hline $\begin{array}{l}\text { Phenomenology and Grounded Theory Re- } \\
\text { search Methods and Design }\end{array}$ & 0.0069 & 0.0115 \\
\hline Higher Education Finance & 0.1255 & 0.0230 \\
\hline Advanced Doctoral Seminar I & 0.4904 & 0.0805 \\
\hline Educational Policy Studies & 0.1545 & 0.0230 \\
\hline Governance in Higher Education & 0.0706 & 0.0115 \\
\hline $\begin{array}{l}\text { Legal Principles in the Administration of Insti- } \\
\text { tutions of Higher Education }\end{array}$ & 0.1545 & 0.0230 \\
\hline Diversity Issues in Higher Education & 0.1545 & 0.0230 \\
\hline $\begin{array}{l}\text { Emerging Qualitative Research Methods and } \\
\text { Design }\end{array}$ & 0.0706 & 0.0115 \\
\hline The American Professoriate & 0.0169 & 0.0115 \\
\hline The Two-Year College & 0.1053 & 0.0345 \\
\hline Directed Research & 0.5389 & 0.0920 \\
\hline Qualitative Research in Education & 0.0389 & 0.0115 \\
\hline Principles of Educational Leadership & 0.2812 & 0.0575 \\
\hline Identity, Schooling and Democratic Education & 0.0389 & 0.0115 \\
\hline Theory and Practice in Educational & 0.3019 & 0.0575 \\
\hline Introductory Doctoral Seminar & 0.2395 & 0.0460 \\
\hline Systematic Inquiry in Educational Leadership & 0.1420 & 0.0460 \\
\hline History of Higher Education & 0.0627 & 0.0230 \\
\hline Ethics and Policy & 0.0071 & 0.0115 \\
\hline Qualitative Research & 0.0071 & 0.0115 \\
\hline Mixed Methods & 0.0071 & 0.0115 \\
\hline
\end{tabular}




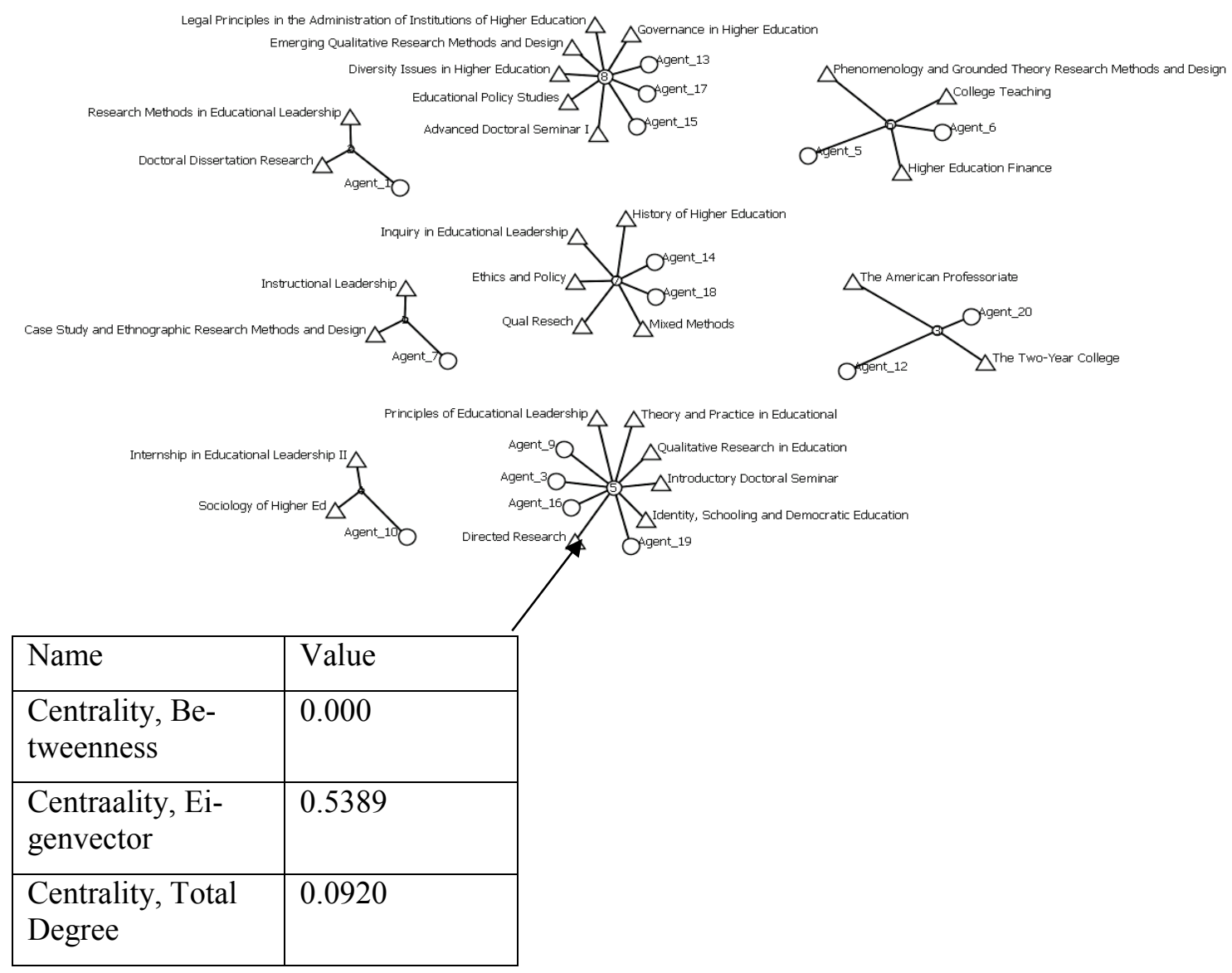

Figure 4: Agent by Classes

Table 5. The Measurements of Agent by Factors

\begin{tabular}{lrr}
\hline & $\begin{array}{c}\text { Centrality, } \\
\text { Eigenvector }\end{array}$ & $\begin{array}{c}\text { Centrality, } \\
\text { Total Degree }\end{array}$ \\
\hline Influences from Previous classes/ readings & -0.0938 & 0.0159 \\
Personal Interest & -0.5082 & 0.0873 \\
Personal life experiences & -0.1567 & 0.0317 \\
Professional Experience & -0.4200 & 0.0873 \\
Relationships & -0.0564 & 0.0079 \\
\hline
\end{tabular}

The survey identified the following five factors had an impact on dissertation topic selection: professional experiences, personal life experiences, relationships, personal interests, and influences from previous classes/readings. According to DNA results (see Table 5), personal interest and professional experience were the most effective factors impacting dissertation topic selection with eigenvector centrality values of -0.5082 and -0.4200 respectively. 
Table 6. The Measurements of Agent by Research Topics

\begin{tabular}{lcc}
\hline & $\begin{array}{c}\text { Centrality, } \\
\text { Eigenvector }\end{array}$ & $\begin{array}{c}\text { Centrality, } \\
\text { Total Degree }\end{array}$ \\
\hline Assessment & -0.0980 & 0.0159 \\
Athletics & -0.0636 & 0.0159 \\
Complexity/ Creativity /Networks & -0.3018 & 0.0476 \\
Distributed Learning/School Choice & -0.3480 & 0.0714 \\
Diversity & -0.1702 & 0.0397 \\
Faculty & -0.0739 & 0.0159 \\
Finance & -0.0725 & 0.0238 \\
Laws/Policy & -0.0975 & 0.0238 \\
Leadership/ Governance & -0.5020 & 0.0794 \\
Mission Creep & -0.0417 & 0.0079 \\
\hline
\end{tabular}

$\mathrm{PhD}$ program with an eigenvector centrality value of -0.5020 (see Table 6). The distributed learning and school choice research topic and the complexity, creativity, and networks research topic were the next two topics most selected by these students with an eigenvector centrality value of -0.3480 and -0.3018 respectively.
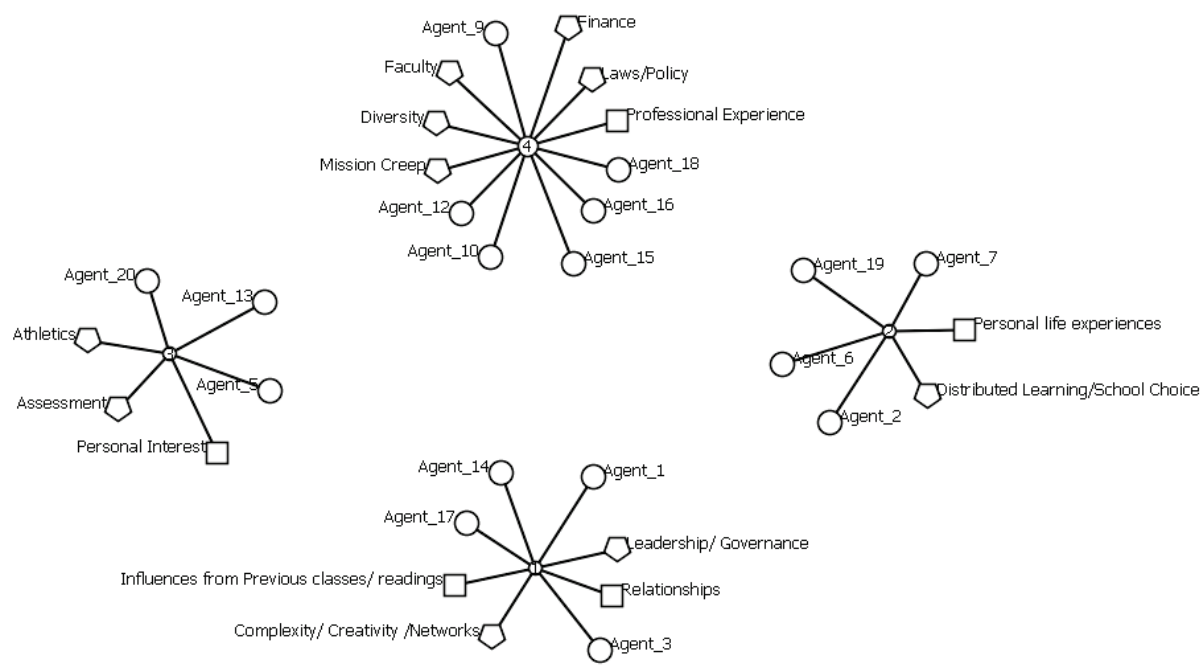

Figure 5. Agent by Knowledge

Total degree centrality values were 0.0873 for both factors. In addition, leadership and governance was the most selected research topic by candidates in the department of Educational Leadership.

For this research, knowledge is determined as factors that influence dissertation topic selection and dissertation topics selected by students in this sample. Researchers applied ORA Newman Grouping to the agent by knowledge matrix to view the clear relationships between students and 
their knowledge. This grouping identified the four clusters displayed in Figure 5. The largest number of students (group 4) were influenced by their personal life experiences, distributed learning/school choice, and law/policy topics for their dissertation topics.

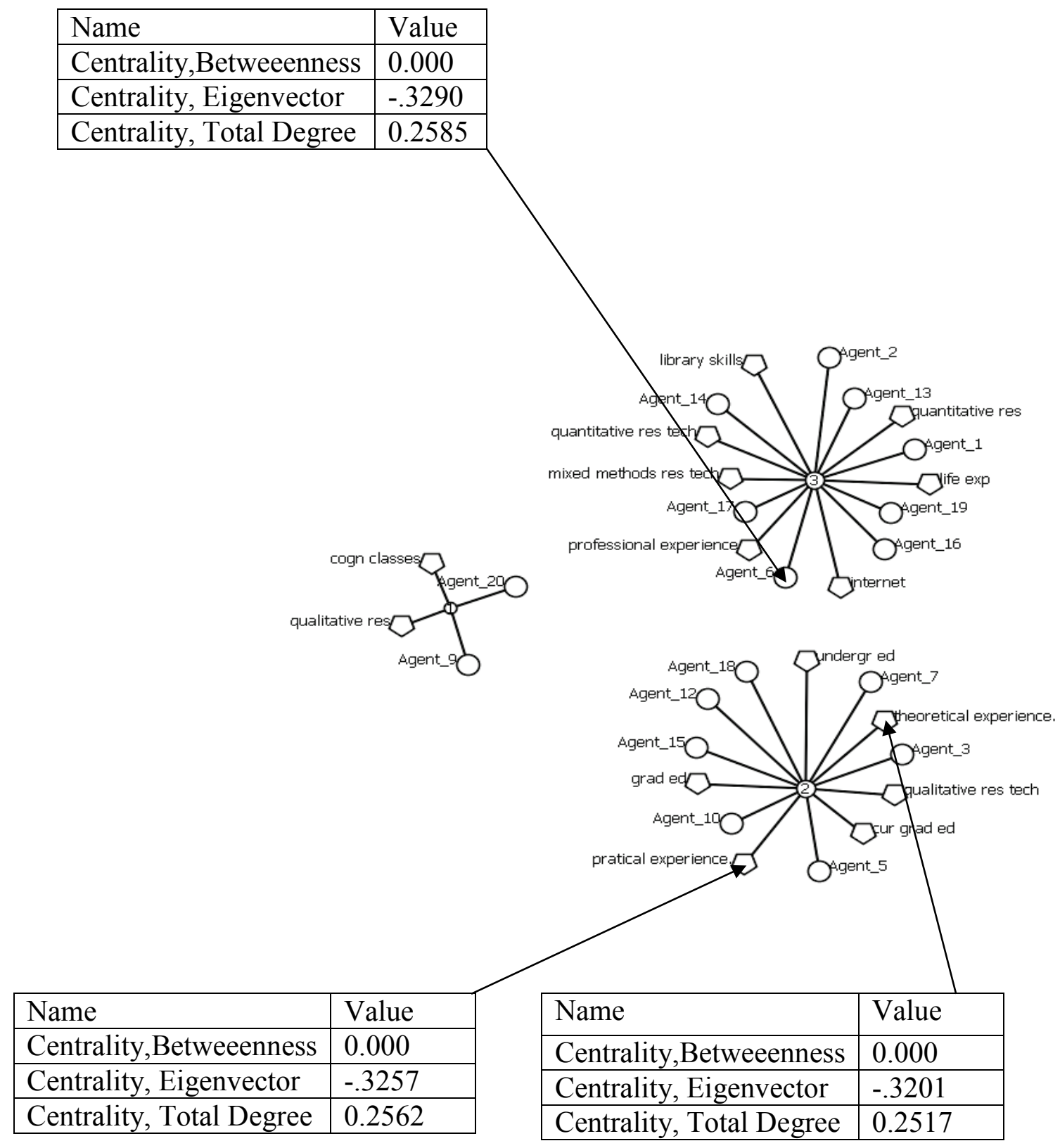

Figure 6: Agent by Belief

The researchers sought students' beliefs for dissertation topic selection in this study. Figure 6 displays the three Newman Grouping clusters identifying the relationship between students and their beliefs with respect to their dissertation topic selection.

Professional experience (-0.3290 eigenvector centrality value), practical experience ( -0.3257 eigenvector centrality value), life experiences ( -0.3228 eigenvector centrality value), and theoretical experience (-0.3201 eigenvector centrality value) were most significant beliefs among fifteen of the students' beliefs for dissertation topic selection. In general, the results show that beliefs 
play an important role in student dissertation topic selections. A complete list of student beliefs is found in Table 7.

Table 7 The Measurements of Agents by Belief

\begin{tabular}{lcr}
\hline & $\begin{array}{c}\text { Centrality, } \\
\text { Eigenvector }\end{array}$ & $\begin{array}{c}\text { Centrality, } \\
\text { Total Degree }\end{array}$ \\
\hline Cognate Classes & -0.2530 & 0.1973 \\
Current Graduate Education & -0.2979 & 0.2336 \\
Graduate Education & -0.2437 & 0.1905 \\
Library Skills & -0.1540 & 0.1202 \\
Life Experiences & -0.3228 & 0.2540 \\
Mixed Methods Research Techniques & -0.2428 & 0.1905 \\
Practical Experience & -0.3257 & 0.2562 \\
Professional Experience & -0.3290 & 0.2585 \\
Qualitative Research Skills & -0.2533 & 0.1995 \\
Qualitative Research Techniques & -0.2893 & 0.2268 \\
Quantitative Research Skills & -0.1971 & 0.1542 \\
Quantitative Research Techniques & -0.1642 & 0.1270 \\
Technology/Internet Skills & -0.1816 & 0.1406 \\
Theoretical Experience & -0.3201 & 0.2517 \\
Undergraduate Education & -0.1938 & 0.1519 \\
\hline
\end{tabular}




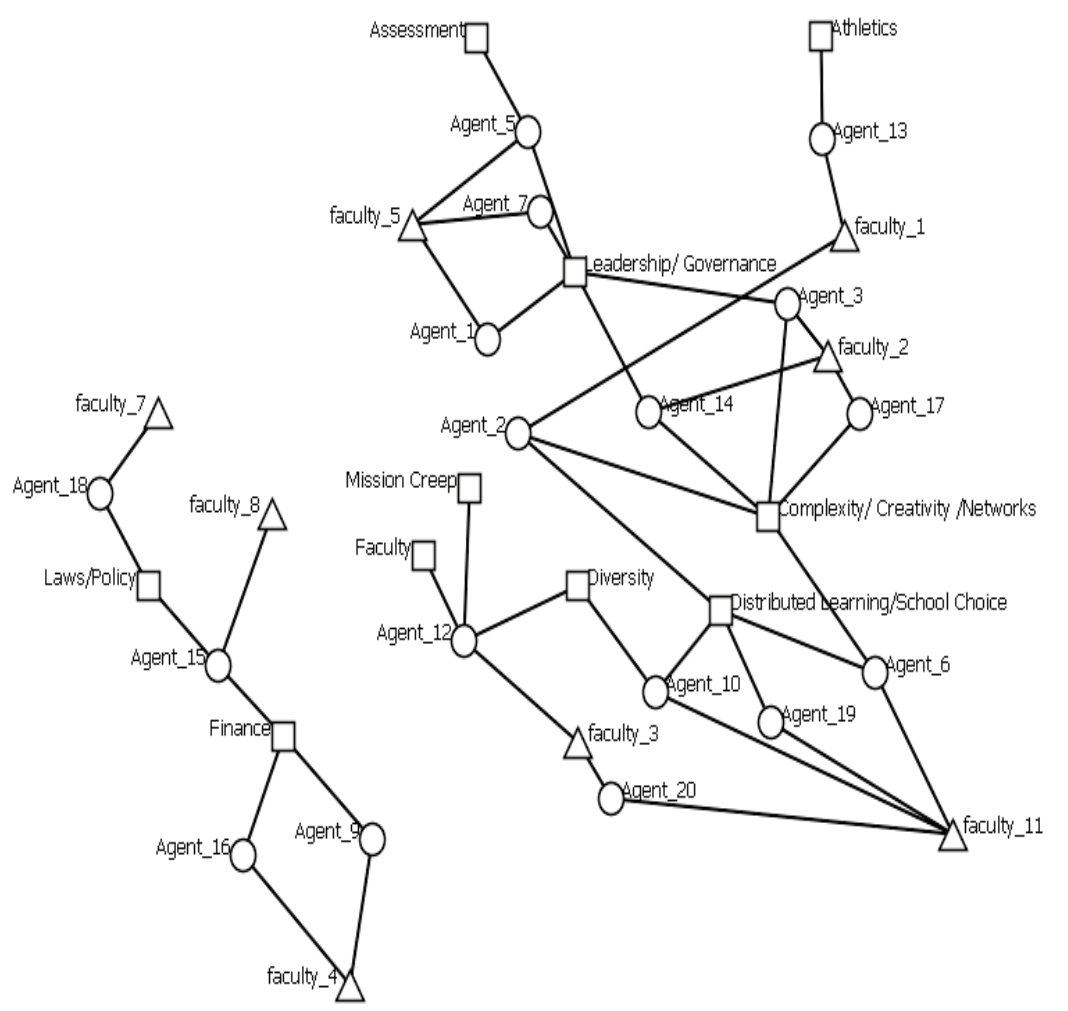

Figure 7. Agent by Chair Research Agenda by Chair

The interaction among agent, dissertation chair, and the chair's research agenda resulted in a $\mathrm{R}^{2}$ value of 0.2344 . Figure 7 displays that the most connected research agenda was associated with the Complexity/Creativity/Network research agenda. The eigenvector associated with this node was -0.7139 . The researchers applied Newman grouping to this data and five clusters were created (see Figure 8). The first group included the interaction between faculty 1 and Agent 13 and the athletics research agenda. Faculty 1 links group 1 with group 3 through agent 2 . This link through faculty 1 established the connection between the athletics research agenda and the complexity/creativity/networks and the distributed learning/school choice research agendas.

The third group displays the relationship between faculty 2 , agent 3 , and agent 17 on distributed learning/school choice and the complexity/creativity/networks research agendas. Faculty 2 links group 3 with group 5 through agents 3,17 , and 14. Group 5 included interactions among faculty 5 , agents 1,5 , and 7 , and also faculty 2 and agent 14 have interactions about assessment, leadership and governance. This link through faculty 2 established the connection between the complexity/creativity/networks and the distributed learning/school choice research agendas with assessment and leadership/governance research agendas. Faculty 11 links group 3 with group 2 through agents 6,19 , and 10 . This link through faculty 11 established the connection between complexity/creativity/networks and the distributed learning/school choice research agendas with diversity, faculty, and mission creep research agendas. Group 2 included the relationship between faculty 3 , agent 12 and agent 20, and faculty 11, agent 10, and agent 20 about the topics of diversity, faculty, and mission creep. Group 4 associates faculty 4 with agents 16 and 9 and faculty 8 with agent 15 , and faculty 7 with agent 18 . This Newman Grouping identified interactions on finance and law/policy research agendas. Researchers note this grouping stands alone with no interactions with the other Newman Groups. 


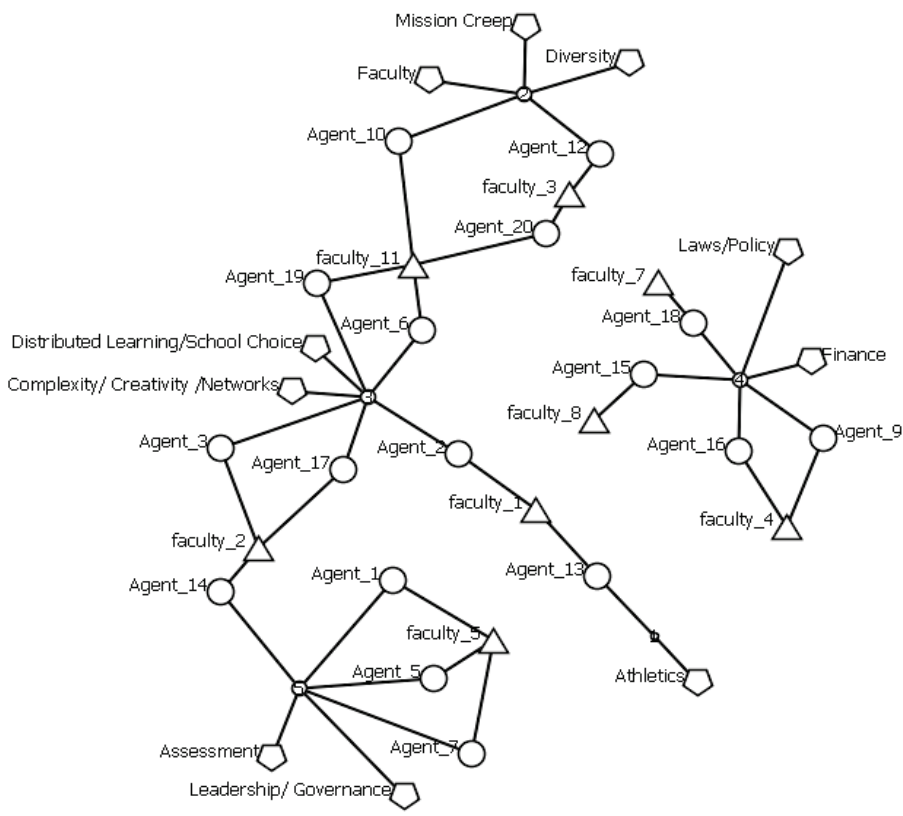

\section{Figure 8. Newman Grouping of Agent by Chair Research Agenda by Chair}

Figure 9 shows the interaction by agent, class influences, and research topic. The directed research class was the most effective course on topic selection with an eigenvector value of 0.5389 . The regression between class influence and the singularly most effective class was $\mathrm{R}^{2}=0.3635$.

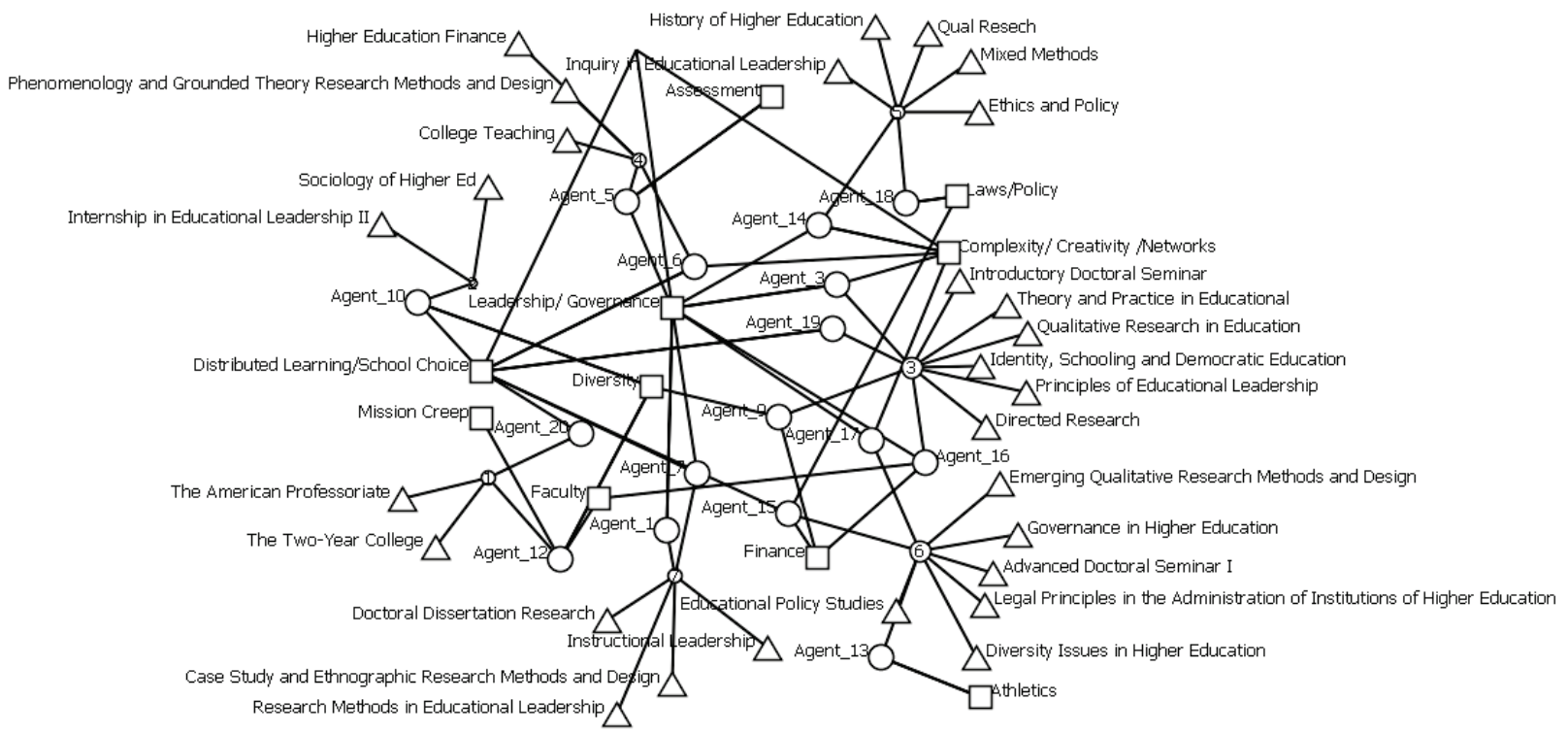

Figure 9. Agent by Class Influences by Research Topic

In Figure 10, agent, belief, and factor interactions were presented. After Newman grouping was applied, three clusters emerged. The most effective beliefs were professional experience with an eigenvector value of 0.3290 in the third group, life experience with an eigenvector value of 
0.3228 in the third group, and practical experience with an eigenvector value of 0.3257 in the second group.

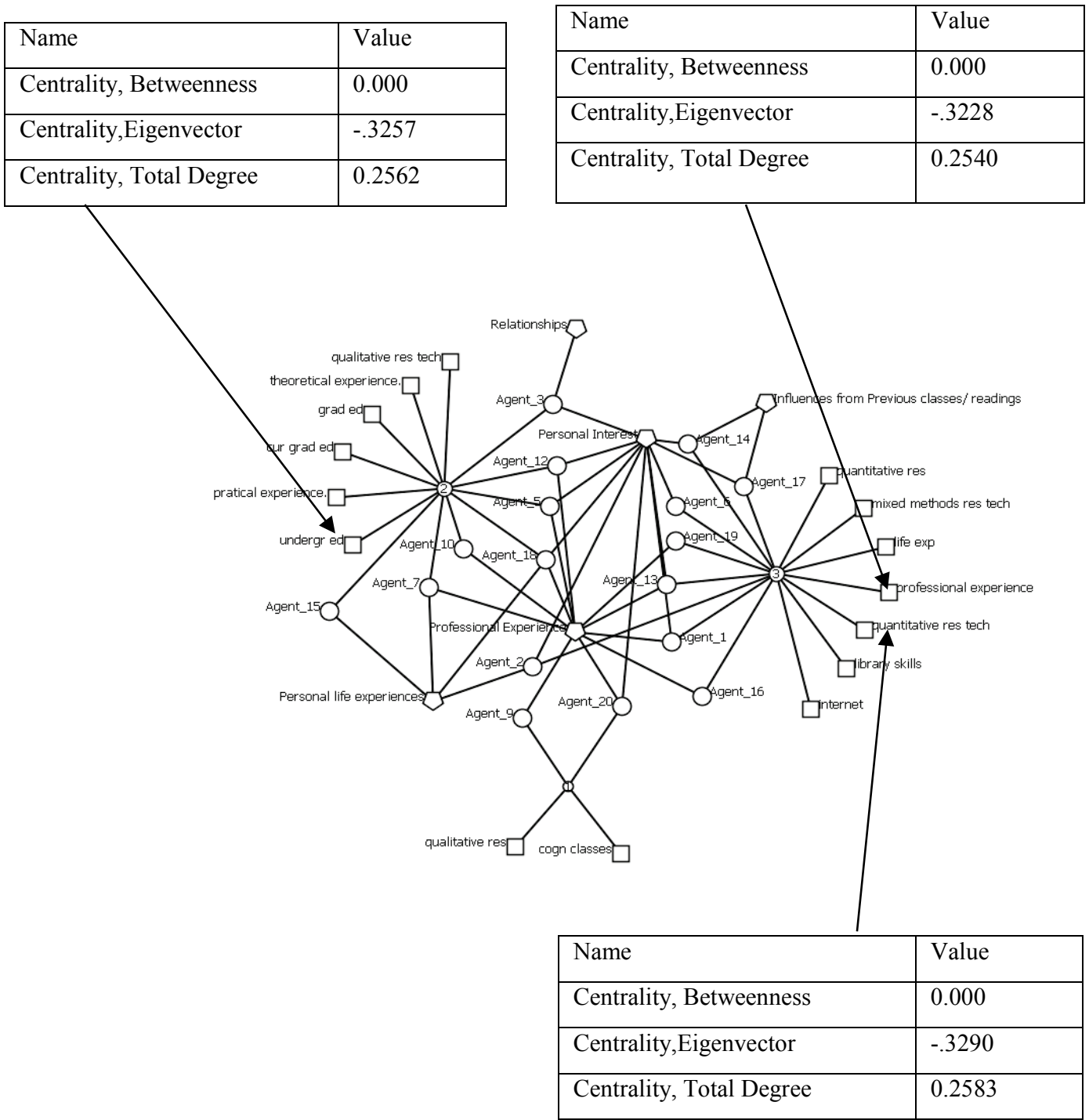

Figure 10. Agent by Belief by Factor

\section{Discussion}

The purpose of this study was to determine the kind of resources available to the student and the influences of the professors' research agenda. Additionally, this study examined the relationship between the students' knowledge and belief in the selection of their dissertation topic.

The result revealed faculty research interest on doctoral students' dissertation topic selection with the research interests with the highest influences as Complexity/Creativity/Networks, Leadership/Governance, and Distributed Learning/School Choice. Constructing meaning from this result indicate that these faculty members have a high degree of total degree centrality which implies that students who choose these research interests will always have these faculty member as 
either their chairs or on their committee's members because of the faculty members' expertise in these fields. These faculty members are also seen or assumed to be information and knowledge gate keepers in their fields of expertise (Schniederjans, 2007). The exclusivity of knowledge resides with these faculty members. Exclusivity of knowledge here indicates ideas and subject matter expertise that others do not have in a particular research interest. It is observed that students with certain research interest always gravitate towards these faculty members with the exclusive knowledge of their research interests.

Another explanation of this phenomenon is the clustering between students and faculty members with similar research interests using the Newman Grouping as indicated by the results from Table 3 faculty members $1,3,4,5$, and 8 . This finding has been supported by literature as one of the factors that influence students' dissertation topic selection (Heiss, 1967; Katz, 1997; Lei, 2009). However, according to Barr (1984), there is distinction between topic selection by students in social sciences and students in the physical science. Research findings reveal topic selections in the physical sciences were often assigned by their advisor compared to about $70 \%$ of students in the social sciences and education who will choose their own research topic. The following question then may be asked, to what degree is a dissertation topic directly assigned by the advisor versus the degree to which a faculty research interest influences a student's topic selection (Barr, 1984; Isaac et al., 1992)?

In determining doctoral topic selection, resources (classes taken) had an influence on student dissertation topic selection. Classes completed during their $\mathrm{PhD}$ programs were identified as resources that influenced a student's dissertation topic selection. The results from our study revealed that three out of the four of the preliminary classes influenced student dissertation topic selection (Kartz, 1997). Our study showed that two leadership courses (Principles of Educational Leadership and Theory and Practices in Educational Leadership) and four research courses (Directed Research, Advanced Doctoral Seminar, Internship in Educational Leadership, and Introductory Doctoral Seminar) were the most influential (see Table 4). This result supports Heiss' (1967) conclusions about the influence of preliminary courses on students dissertation topic selection.

Student's previous knowledge influences their dissertation topic selection. The study results revealed personal interest and professional experience played a high role in influencing a student's dissertation topic selection. While this finding confirms extant literature on the role of past experience, it is, however, interesting to note that peer influence played a lesser influence on a student's dissertation topic selection contrary to general expectation (Heiss, 1967). Instead, personal interest and professional experience had a stronger influence on a student's dissertation topic selection. The implication of this result is that students, even while considering their faculty member's research interest, also give consideration to their personal interests and professional experiences when determining dissertation topics. In this sample, $50 \%$ of the students based their dissertation topic selection on their personal interest while $40 \%$ based their selection on their professional experiences. This result may have implications on student's mentor selection determination.

Student's existing belief also influences their dissertation topic selection. The beliefs identified related to theoretical experiences, professional experiences, practical experiences, and life experiences (see Table 7). The result of this study suggests that students' backgrounds influence their dissertation topic selection more than their experiences in the PhD program itself (Isaac et al., 1989; Heiss, 1967). A rather important explanation is that some students may unknowingly enter the doctoral program with a preconceived idea of their research interest based on their beliefs (theoretical experiences, professional experiences, practical experiences, and life experiences) when selecting their dissertation topics. 
The beauty of dynamic network analysis in deconstructing this connection is its capacity to determine network relations and interactions among agents. Figure 7 displays the relationship among agents, chairs, and their research interests. The result revealed that the most connected research agenda were Complexity/Creativity/Network. Figure 7 also shows the interactions between students and their chairs and identifies the nodes with the shortest connections and the most links (betweenness centrality). Literature also alludes to these same relationships between chairs and their students (Barr, 1984; Heiss, 1967).

In Figure 10, agent, belief, and factor interactions were examined. After Newman Grouping was applied, three clusters emerged. The most effective beliefs were professional experience, life experience, and practical experience. The implication of this is that professional experience, life experiences, and practical experiences were preponderant network factors that influenced a student's dissertation topic selection supporting Heiss' (1967) conclusions.

\section{Conclusion}

When considering dissertation topic selection, research reveals that students are bombarded by varying considerations. These considerations can sometimes be confusing or even overwhelming. Therefore, an understanding of these considerations could be instructive to include in a doctoral student's orientation and advising in order to eliminate the stress and confusion that may follow this process. Another important conclusion is that students are influenced by more than one single factor when selecting their dissertation topic, some factors are more important than others. This study, as mentioned earlier, can be instructive in student advising about dissertation topic selection. However, this study is limited by very little literature on dissertation topic selection and by time available to collect data as this study was implemented as part of a semester course work.

In programing and institutional curriculum planning, decisions on preliminary classes for most departments should be intentional because, as revealed by this study, dissertation topic selection by doctoral students may be fixated on the choice of these classes. As shown in this research, preliminary classes clearly shaped a student's dissertation topic selection. These preliminary courses identified in this study as resources helped to shape doctoral student dissertation topic selection decisions. Complexity, creativity, and networks were all topics thoroughly discussed during preliminary coursework and they were the most central to topic selection. This may be good if it is a deliberate effort to set the specialization of the department in a certain direction but this can also be counterproductive if it is not. Departments must therefore be deliberate in determining the classes identified as preliminary classes since these classes can influence the outcome of students' dissertation topic selection.

The use of dynamic network analysis in this study helped to explicate the importance of the interaction between the faculty research agenda and the students' dissertation topic selection. This was shown by how much faculty research agenda influenced students topic selection as faculty with knowledge specific subject matter attracted students with those research interests. This is evident by the number of clusters formed around particular research interest.

Finally, this study showed the influence of previous professional experience, life experiences and practical experience in determining students dissertation topic selection. The result helped to highlight the relationships between a student's knowledge and belief in determining dissertation topic selection. This may be important for student advising and guidance. Further research may be needed to determine which of these students' past experiences have a greater influence. Even though this study revealed little influence of peer group dissertation topic selection, it may be interesting to study why this is so and the contributions of peer interaction in dissertation topic selection process. 


\section{References}

Adderley, K., Ashwin, C., Bradbury, P., Freeman, D., Goodlad, S., Greene, J., Jenkins, D., Rae, J., \& Uren, O. (1975). Project methods in higher education. London: Society for Research into Higher Education.

Ashworth, M., \& Carley, K. (2006). Who you know vs. what you know: The impact of social position and knowledge on team performance. Journal of Mathematical Sociology, 30(1), 43-75.

Bargar, R. R., \& Duncan, J. K. (1982). Cultivating creative endeavor in doctoral research. The Journal of Higher Education, 53(1), 1-31.

Barr, M. A. (1984). The selection of a dissertation topic: Elements influencing student choice. (Doctoral dissertation, The Ohio State University). Retrieved from

http://search.proquest.com.libproxy.clemson.edu/docview/303300654

Berelson, B. (1960). Graduate education in the United States. New York: McGraw-Hill.

Bonacich, P. (1972a). Factoring and weighting approaches to status scores and clique detection. Journal of Mathematical Sociology, 2, 113-120.

Bonacich, P. (1972b). Technique for analyzing overlapping memberships. In H. Costner (Ed.), Sociological methodology (pp. 176-185). San Francisco: Jossey-Bass.

Borgatti, S. P., Mehra, A., Brass, D. J., \& Labianca, G. (2009). Network analysis in the social sciences. Science, 323(5916), 892-895.

Carley, K. (2002). Summary of key network measures for characterizing organizational architectures. Unpublished Document: Carnegie Mellon University.

Carley, K. M. (2003). Dynamic network analysis. Paper presented at the NRC workshop on the Social Network Modeling and Analysis.

Carley, K. M. (2010). ORA: Organizational risk analyzer, Version 2.0, January 2010. Pittsburgh: Carnegie Mellon University.

Clauset, A., Newman, M.G., \& Moore, C. (2004). Finding community structure in very large networks. Physical Review, 70(6), 1-6.

Dunham, D. R., \& Lumsden, D. B. (1981). Dissertation research: Part 1, its relation to human thought. Community/Junior College Research Quarterly, 5(2), 121-127.

Freeman, L. C. (1979). Centrality in social networks conceptual clarification. Social Networks, 1(3), 215239.

Gatrell, A. C. (1991). Teaching students to select topics for undergraduate dissertations in geography. Journal of Geography in Higher Education, 15(1), 15-24.

Heiss, A. M. (1967). Berkeley doctoral students appraise their academic programs. Education Record, 48, $30-44$.

Isaac, P. D., Koenigsknecht, R. A., Malaney, G. D., \& Karras, J. E. (1989). Factors related to doctoral dissertation topic selection. Research in Higher Education, 30(4), 357-373.

Isaac, P. D., Quinlan, S. V., \& Walker, M. M. (1992). Faculty perceptions of the doctoral dissertation. The Journal of Higher Education, 63(3), 241-268.

Katz, E. L. (1997). Key players in the dissertation process. New Directions for Higher Education, 99, 5-16.

Knoke, D., \& Kuklinski, J. H. (1982). Network analysis. Beverly Hills, CA: Sage

Laumann, E., Marsden, P., \& Prensky, D. (1983). The boundary specification problem in network analysis. In R. Burt \& M. Minor (Ed.), Applied network analysis (18-34). Beverly Hills, CA: Sage

Leedy, P. D., \& Ormrod, J. E. (2005). Practical research: Planning and design (8th ed.). Upper Saddle River, NJ: Prentice Hall 
Lei, S. A. (2009). Strategies for finding and selecting an ideal thesis or dissertation topic: A review of literature. College Student Journal, 43(4), 1324-1332.

Luse, A., Mennecke, B., \& Townsend, A. (2012). Selecting a research topic: A framework for doctoral students. International Journal of Doctoral Studies, 7, 143-153. Retrieved from http://ijds.org/Volume7/IJDSv7p143-153Luse330.pdf

Marin, A., \& Wellman, B. (2011). Social network analysis: An Introduction. In J. Scott and P. J. Carrington (Eds), The Sage handbook of social network analysis. Thousand Oaks, CA: Sage.

Pinsonneault, A., \& Kraemer, K. L. (1993). Surveys research methodology in management information systems: An assessment. Journal of Management Information Systems, 10(2), 75-105.

Ray, S. (2007). Selecting a doctoral supervisor: Analytical hierarchy approach to the multiple criteria problem. International Journal of Doctoral Studies, 2, 23-32. Retrieved from http://www.ijds.org/Volume2/IJDSv2p023-032Ray18.pdf

Schniederjans, M. (2007). A proposed Ph.D. student bill of rights. International Journal of Doctoral Studies, 2, 1-8. Retrieved from http://www.ijds.org/Volume2/IJDSv2p001-008Schniederjans22.pdf

Uhl-Bien, M., Marion, R., \& McKelvey, B. (2007). Complexity leadership theory: Shifting leadership from the industrial age to the knowledge era. Leadership Quarterly, 18(4), 298-318. DOI: 10.1016/j.leaqua.2007.04.002

Useem, B. (1997). Choosing a dissertation topic. PS: Political Science and Politics, 30(2), 213-216.

Wasserman, S., \& Faust, K. (1994). Social network analysis. Cambridge: Cambridge University Press.

Ziolkowski, T. (1990). The Ph.D. Squid. The American Scholar, 59(2), 177-195.

\section{Biographies}

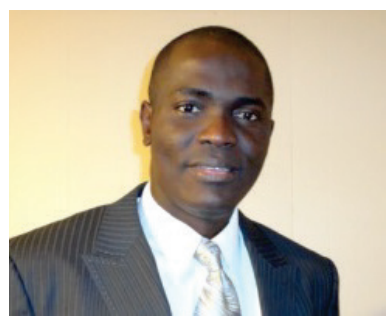

Anthony Abidemi Olalere earned a B.S. Political in 1991 from the Lagos State University and an M.S. in Political Science in 2008 from the University of Ibadan. In 2010 he earned a Master's in Business Administration from Strayer University and a PhD in Educational Leadership in 2013 from the Clemson University. His research interests include Complexity leadership and Dynamic Network Analysis.

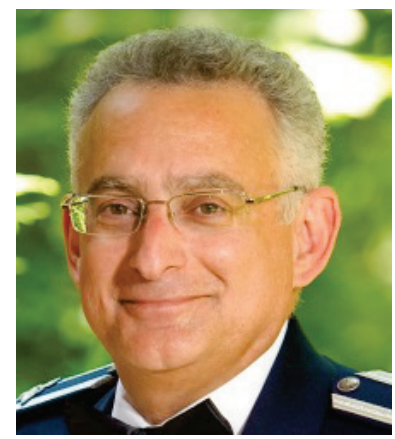

Edward B. De Iulio earned a B.S. in Industrial Management in 1975 and an M.S. in Computer Science in 1976 from the Georgia Institute of Technology. He is a PhD candidate in the Educational Leadership program, Higher Education track at Clemson University. He is currently the Assistant Director of the Academic Advising Center for the College of Business and Behavioral Science at Clemson University. 


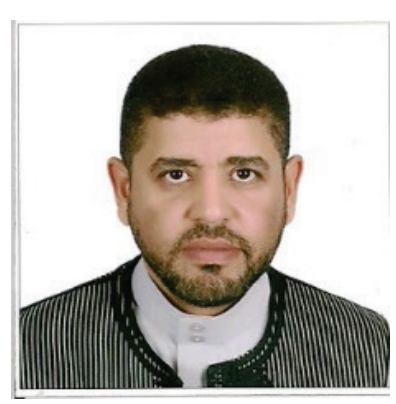

Amin Marei Aldarbag received his B.S. degree in Accounting from University of Benghazi, Libya, in 1994, and Master degree in Accounting from Libyan Academy, Benghazi, Libya, in 2002, and Ph.D. degree in Educational Leadership from Clemson University, Clemson, South Carolina, the USA, in 2013. He is a Senior Lecturer at University of Omer Almukhtar. Research interests include leadership theories, education policies in business school, and accounting education.

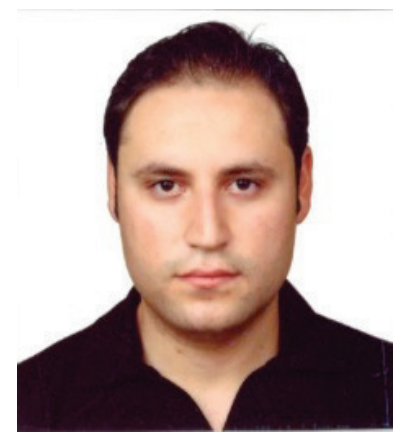

Mehmet Akif Erdener received his B.S. degree in Science Education from Selcuk University, Turkey, in 2006, and MEd. in Administration $\&$ Supervision and Ph.D. degrees in Educational Leadership from Clemson University, Clemson, South Carolina, US in 2009 and 2013, respectively. He is currently a researcher at the Necatibey School of Education, Balikesir University. His research interests include homeschool and community partnership, organizational theories, school management, education policies and accountability. 